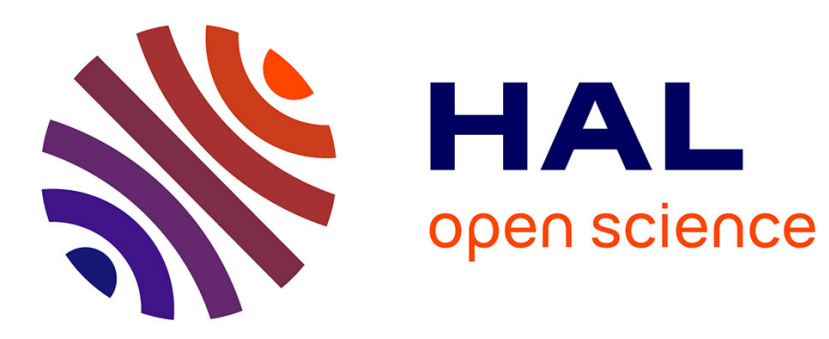

\title{
The role of money and monetary policy in crisis periods: the Euro area case
}

\author{
Jonathan Benchimol, André Fourçans
}

\section{To cite this version:}

Jonathan Benchimol, André Fourçans. The role of money and monetary policy in crisis periods: the Euro area case. 2012. hal-00672806

\section{HAL Id: hal-00672806 https://essec.hal.science/hal-00672806}

Preprint submitted on 22 Feb 2012

HAL is a multi-disciplinary open access archive for the deposit and dissemination of scientific research documents, whether they are published or not. The documents may come from teaching and research institutions in France or abroad, or from public or private research centers.
L'archive ouverte pluridisciplinaire HAL, est destinée au dépôt et à la diffusion de documents scientifiques de niveau recherche, publiés ou non, émanant des établissements d'enseignement et de recherche français ou étrangers, des laboratoires publics ou privés. 


\title{
The role of money and monetary policy in crisis periods : the Euro area case
}

\author{
Research Center \\ ESSEC Working Paper 1201
}

2012

Jonathan Benchimol

André Fourçans 


\title{
The role of money and monetary policy in crisis periods: the Euro area case
}

\author{
Jonathan Benchimol* and André Fourçans ${ }^{\dagger}$
}

February 1st, 2012

\begin{abstract}
In this paper, we test two models of the Eurozone, with a special emphasis on the role of money and monetary policy during crises. The role of separability between money and consumption is investigated further and we analyse the Euro area economy during three different crises: 1992, 2001 and 2007. We find that money has a rather significant role to play in explaining output variations during crises whereas, at the same time, the role of monetary policy on output decreases significantly. Moreover, we find that a model with non-separability between consumption and money has better forecasting performance than a baseline separable model over crisis periods.
\end{abstract}

Keywords: Euro area, Money, DSGE forecasting. JEL Classification: E31, E51, E58.

\footnotetext{
${ }^{*}$ Economics Department, ESSEC Business School and CES, University Paris 1 Panthéon-Sorbonne, 106-112 Boulevard de l'Hôpital, 75647 Paris cedex 13. Email: jonathan.benchimol@essec.edu

${ }^{\dagger}$ Economics Department, ESSEC Business School, Avenue Bernard Hirsch, 95021 Cergy Pontoise Cedex 2, France. Corresponding author Phone: +33-1-34433017, Fax: +33-1-34433689. Email: fourcans@essec.edu
} 


\section{Introduction}

The ability to accurately forecast the future path for macroeconomic series such as output or inflation is crucial information for the business sector, government and central bank in their decision-making process. Christiano, Trabandt, and Walentin (2010) show that Dynamic Stochastic General Equilibrium (DSGE) models provide valuable information about business cycle dynamics and the effects of various economic shocks on the economy. For all those reasons, DSGE models are increasingly being utilized by central banks and other policy-making institutions to assist with policy decisions, as pointed by Edge and Gürkaynak (2010).

In policy analysis, it is believed that monetary policy has long and variable effects on the overall economy. To capture such complex interactions between policy variables and the economy as a whole, macroeconomic forecasting becomes indispensable in actual policy making (Blinder, 1997; Diebold, 1998). Sims and Zha (1998) introduced Bayesian methods to vector autoregressive (VAR) models to improve the accuracy of out-of-sample forecasts in a dynamic multivariate framework. They showed how to compute Bayesian probability distributions or error bands around out-of-sample forecasts. More recently, researchers have started to examine the forecasting performance of these models. In one such investigation, Smets and Wouters (2007) show that a DSGE model can generate forecasts that have a lower root mean-squared deviation (RMSD) than a Bayesian Vector Autoregression (BVAR).

On the other hand, Edge, Kiley and Laforte (2010) show that the out-ofsample forecasting performance of the Federal Reserve Board's new DSGE model for the U.S. economy (EDO) is in many cases better than their largescale macro-econometric model (FRB/US).

In a DSGE framework applied to the Eurozone, Benchimol and Fourçans (2012) show that the role of money with respect to the economy, especially on output dynamics, increases with risk aversion. Yet they don't develop a complete analysis of the role of money and of monetary policy during crisis periods. The purpose of our paper is to fill this gap by focusing on the fluctuations of micro and macro parameters; on variance decompositions of variables with respect to shocks; and on output and inflation forecasts.

They have shown that money has an explicit role when risk aversion is high enough, which may be the case during crisis periods. Yet, these periods do not last long. And other parameters changes in the very short term may also affect the role of money and monetary policy. That is why, in the present article, we use relatively small samples for the estimations, in 
order to capture the impact of very short term parameters changes on the dynamics of the model.

First, we compare two types of New Keynesian models in a DSGE framework. The first model is a standard one whereby money is included in the utility function with a separability assumption, as in the baseline model of Galí (2008). The second model introduces money in the utility function by assuming non-separability between real money balances and consumption as in Benchimol and Fourçans (2012). By using Bayesian techniques, we estimate these two models with Eurozone data over three different crises: during speculative attacks on currencies in the European Exchange Rate Mechanism (ERM) at the beginning of the 1990s (Black Wednesday crisis); following the bursting of the Dot-com bubble at the beginning of 2001 (Dotcom crisis) ; and during the subprime crisis from 2007 to 2010 (Subprime crisis).

Second, we analyze the results on the dynamics of the model, by studying the variations of micro and macro parameters during these crisis periods as well as the variance decomposition of the variables (notably current output, flexible-price output and inflation) with respect to structural shocks (preference shock, technology shock, money shock and interest rate shock). We also study the forecasting performances of the two models over the periods under scrutiny. Focusing on these three periods sheds light on the specific role of money and monetary policy in crisis situations and leads to interesting results as to output and inflation dynamics during these periods.

The results show that the role of money increases during crises. It also demonstrates that a New Keynesian model with non-separable preferences between money and consumption is able to better forecast output than a simple New Keynesian model with separable preferences during crises.

The study leads to policy implications as to the conduct of monetary policy, especially during crisis periods.

In Section 2, we present the models used for the empirical analysis presented in Section 3. We analyze the ERM crisis in Section 4, the Dot-com crisis in Section 5, and the Subprime crisis in Section 6. For each crisis, we provide estimated parameters, variance decompositions and analyse predictive properties of each model over time. We discuss the results and compare the three crises in Section 7. Section 8 concludes. 


\section{The models}

These two models consist of households that supply labor, purchase goods for consumption, hold money and bonds, and firms that hire labor and produce and sell differentiated products in monopolistically competitive goods markets. Each firm sets the price of the good it produces, but not all firms reset their price during each period. Households and firms behave optimally: households maximize the expected present value of utility, and firms maxi-

mize profits. There is also a central bank that controls the nominal rate of interest.

\subsection{The separable baseline model}

The following New Keynesian DSGE model is mainly inspired by Galí (2008), and serves as a baseline model.

\subsubsection{Households}

We assume a representative infinitely-lived household, seeking to maximize

$$
E_{t}\left[\sum_{k=0}^{\infty} \beta^{k} U_{t+k}\right]
$$

where $U_{t}$ is the period utility function and $\beta<1$ is the discount factor.

We assume the existence of a continuum of goods represented by the interval $[0,1]$. The household decides how to allocate its consumption expenditures among the different goods. This requires that the consumption index $C_{t}$ be maximized for any given level of expenditures. Furthermore, and conditional on such optimal behavior, the period budget constraint takes the form

$$
P_{t} C_{t}+M_{t}+Q_{t} B_{t} \leq B_{t-1}+W_{t} N_{t}+M_{t-1}
$$

for $t=0,1,2 \ldots, P_{t}$ is an aggregate price index, $M_{t}$ is the quantity of money holdings at time $t, B_{t}$ is the quantity of one-period nominally riskless discount bonds purchased in period $t$ and maturing in period $t+1$ (each bond pays one unit of money at maturity and its price is $Q_{t}$ where $i_{t}=-\log Q_{t}$ is the short term nominal rate), $W_{t}$ is the nominal wage, and $N_{t}$ is hours of work (or the measure of household members employed).

The above sequence of period budget constraints is supplemented with a solvency condition, such as $\forall t \lim _{n \longrightarrow \infty} E_{t}\left[B_{n}\right] \geq 0$, in order to avoid Ponzi-type 
schemes. Preferences are measured with a common time-separable utility function (MIU). Under the assumption of a period utility given by

$$
U_{t}=e^{\varepsilon_{t}^{P}}\left(\frac{C_{t}^{1-\sigma}}{1-\sigma}+\frac{\gamma e^{\varepsilon_{t}^{m}}}{1-\vartheta}\left(\frac{M_{t}}{P_{t}}\right)^{1-\vartheta}-\frac{\chi N_{t}^{1+\eta}}{1+\eta}\right)
$$

where consumption, labor, money and bond holdings are chosen to maximize (3) subject to the budget constraint (2) and the solvency condition. $\sigma$ is the coefficient of relative risk aversion of households (or the inverse of the intertemporal elasticity of substitution), $\vartheta$ is the inverse of the elasticity of money holdings with respect to the interest rate, and $\eta$ is the inverse of the elasticity of work effort with respect to the real wage. The utility function also contains two structural shocks: $\varepsilon_{t}^{p}$ is a general shock to preferences that affects the intertemporal substitution of households (preference shock accounts for changes in the marginal rate of substitution between goods, real money balances and work) and $\varepsilon_{t}^{m}$ is a money shock (it accounts for changes in households' money holdings). $\gamma$ and $\chi$ are positive scale parameters.

\subsubsection{Firms}

We assume a continuum of firms indexed by $i \in[0,1]$. Each firm produces a differentiated good but uses an identical technology with the following production function,

$$
Y_{t}(i)=A_{t} N_{t}(i)^{1-\alpha}
$$

where $A_{t}=\exp \left(\varepsilon_{t}^{a}\right)$ is the level of technology assumed to be common to all firms and to evolve exogenously over time, $\varepsilon_{t}^{a}$ is the technology shock, and $\alpha$ is the measure of decreasing returns.

All firms face an identical isoelastic demand schedule, and take the aggregate price level $P_{t}$ and aggregate consumption index $C_{t}$ as given. As in the standard Calvo (1983) model, our generalization features monopolistic competition and staggered price setting. At any time $t$, only a fraction $1-\theta$ of firms, with $0<\theta<1$, can reset their prices optimally, while the remaining firms index their prices to lagged inflation.

\subsubsection{Central bank}

Finally, the model is closed by adding the monetary policy smoothed Taylortype reaction function:

$$
\hat{\imath}_{t}=\left(1-\lambda_{i}\right)\left(\lambda_{\pi}\left(\hat{\pi}_{t}-\pi^{*}\right)+\lambda_{x}\left(\hat{y}_{t}-\hat{y}_{t}^{f}\right)\right)+\lambda_{i} \hat{\imath}_{t-1}+\varepsilon_{t}^{i}
$$


where $\lambda_{\pi}$ and $\lambda_{x}$ are policy coefficients reflecting the weight on inflation and on the output gap; the parameter $0<\lambda_{i}<1$ captures the degree of interest rate smoothing. $\varepsilon_{t}^{i}$ is an exogenous ad hoc shock accounting for fluctuations of nominal interest rate.

\subsubsection{Solution}

The solution of this model leads to six equations with six variables: flexibleprice output $\left(\hat{y}_{t}^{f}\right)$, inflation $\left(\hat{\pi}_{t}\right)$, output $\left(\hat{y}_{t}\right)$, real money balances $\left(\widehat{m p}_{t}\right)$, and nominal interest rate $\left(\hat{\imath}_{t}\right)$; and four structural shocks which are assumed to follow a first-order autoregressive process with an i.i.d.-normal error term such as $\varepsilon_{t}^{k}=\rho_{k} \varepsilon_{t-1}^{k}+\omega_{k, t}$ where $\varepsilon_{k, t} \sim N\left(0 ; \sigma_{k}\right)$ for $k=\{p, m, i, a\}$. The lowercase superscript $\left({ }^{\wedge}\right)$ denotes the log-linearized (around the steady state) form of the original aggregated variables.

$$
\begin{gathered}
\hat{y}_{t}^{f}=\frac{1+\eta}{\sigma(1-\alpha)+\eta+\alpha} \varepsilon_{t}^{a}+\frac{(1-\alpha)\left(\log (1-\alpha)+\rho_{n}-\log \left(\frac{\varepsilon}{\varepsilon-1}\right)\right)}{\sigma(1-\alpha)+\eta+\alpha} \\
\hat{\pi}_{t}=\beta E_{t}\left[\hat{\pi}_{t+1}\right]+\frac{(1-\theta)(1-\beta \theta)(\sigma(1-\alpha)+\eta+\alpha)}{\theta(1-\alpha+\alpha \varepsilon)}\left(\hat{y}_{t}-\hat{y}_{t}^{f}\right) \\
\hat{y}_{t}=E_{t}\left[\hat{y}_{t+1}\right]-\sigma^{-1}\left(\hat{\imath}_{t}-E_{t}\left[\hat{\pi}_{t+1}\right]-\rho_{c}\right)-\sigma^{-1} E_{t}\left[\Delta \varepsilon_{t+1}^{p}\right] \\
\widehat{m p}_{t}=\frac{\sigma}{\vartheta} \hat{y}_{t}-\frac{a_{2}}{\vartheta} \hat{\imath}_{t}-\frac{\rho_{m}}{\vartheta}+\frac{1}{\vartheta} \varepsilon_{t}^{m} \\
\hat{\imath}_{t}=\left(1-\lambda_{i}\right)\left(\lambda_{\pi}\left(\hat{\pi}_{t}-\pi^{*}\right)+\lambda_{x}\left(\hat{y}_{t}-\hat{y}_{t}^{f}\right)\right)+\lambda_{i} \hat{\imath}_{t-1}+\varepsilon_{t}^{i}
\end{gathered}
$$

where

$$
\begin{aligned}
& \rho_{m}=-\log (\gamma)+a_{1} \\
& \rho_{n}=-\log (\chi) \\
& \rho_{c}=-\log (\beta) \\
& \text { with } a_{1}=\log \left(1-e^{-\frac{1}{\beta}}\right)-\frac{\frac{1}{\beta}}{e^{\frac{1}{\beta}}-1} \text { and } a_{2}=\frac{1}{e^{\frac{1}{\beta}}-1} .
\end{aligned}
$$

$\varepsilon_{t}^{m}$ is the shock on real money balances, $\varepsilon_{t}^{p}$ is the shock preferences, $\varepsilon_{t}^{i}$ is the exogenous component of the interest rate and $\varepsilon_{t}^{a}$ is the technology shock. 


\subsection{The non-separable model}

As in the previous model the representative infinitely-lived household seeks to maximize

$$
E_{t}\left[\sum_{k=0}^{\infty} \beta^{k} U_{t+k}\right]
$$

Now, the period utility function $U_{t}$ is such as:

$$
U_{t}=e^{\varepsilon_{t}^{p}}\left(\frac{1}{1-\sigma}\left((1-b) C_{t}^{1-\nu}+b e^{\varepsilon_{t}^{m}}\left(\frac{M_{t}}{P_{t}}\right)^{1-\nu}\right)^{\frac{1-\sigma}{1-\nu}}-\frac{\chi}{1+\eta} N_{t}^{1+\eta}\right)
$$

where consumption, labor, money and bond holdings are chosen to maximize (11) subject to the same budget constraint and the same solvency condition as in the baseline model. This CES utility function depends positively on the consumption of goods, $C_{t}$, positively on real money balances, $M_{t} / P_{t}$, and negatively on labour $N_{t}$, as in the baseline model. $\nu$ is the inverse of the elasticity of money holdings with respect to the interest rate, and can be seen as a non separability parameter. $b$ and $\chi$ are positive scale parameters. We use the same production function and Taylor rule as in the baseline model.

This New Keynesian DSGE model was developed in Benchimol and Fourçans (2012). As in the first model, it leads to six equations with six macro variables: flexible-price output $\left(\hat{y}_{t}^{f}\right)$, flexible-price real money balances $\left(\widehat{m p}_{t}^{f}\right)$, inflation $\left(\hat{\pi}_{t}\right)$, output $\left(\hat{y}_{t}\right)$, nominal interest rate $\left(\hat{\imath}_{t}\right)$, and real money balances $\left(\widehat{m p}_{t}\right)$, such as

$$
\begin{gathered}
\hat{y}_{t}^{f}=v_{a}^{y} \hat{a}_{t}+v_{m}^{y} \widehat{m p}_{t}^{f}-v_{c}^{y}+v_{s m}^{y} \varepsilon_{t}^{M} \\
\widehat{m p}_{t}^{f}=v_{y+1}^{m} E_{t}\left[\hat{y}_{t+1}^{f}\right]+v_{y}^{m} \hat{y}_{t}^{f}+\frac{1}{\nu} \varepsilon_{t}^{M} \\
\hat{\pi}_{t}=\beta E_{t}\left[\hat{\pi}_{t+1}\right]+\kappa_{x}\left(\hat{y}_{t}-\hat{y}_{t}^{f}\right)+\kappa_{m}\left(\widehat{m p}_{t}-\widehat{m p}_{t}^{f}\right) \\
\hat{y}_{t}=E_{t}\left[\hat{y}_{t+1}\right]-\kappa_{r}\left(\hat{\imath}_{t}-E_{t}\left[\hat{\pi}_{t+1}\right]\right)+\kappa_{m p} E_{t}\left[\Delta \widehat{m p}_{t+1}\right] \\
+\kappa_{s p} E_{t}\left[\Delta \varepsilon_{t+1}^{P}\right]+\kappa_{s m} E_{t}\left[\Delta \varepsilon_{t+1}^{M}\right] \\
\widehat{m p}_{t}=\hat{y}_{t}-\kappa_{i} \hat{\imath}_{t}+\frac{1}{\nu} \varepsilon_{t}^{M}
\end{gathered}
$$




$$
\hat{\imath}_{t}=\left(1-\lambda_{i}\right)\left(\lambda_{\pi} \hat{\pi}_{t}+\lambda_{x}\left(\hat{y}_{t}-\hat{y}_{t}^{f}\right)\right)+\lambda_{i} \hat{\imath}_{t-1}+\varepsilon_{t}^{i}
$$

where

$$
\begin{aligned}
& v_{a}^{y}=\frac{1+\eta}{\left(\nu-(\nu-\sigma) a_{1}\right)(1-\alpha)+\eta+\alpha} \\
& v_{m}^{y}=\frac{(1-\alpha)(\nu-\sigma)\left(1-a_{1}\right)}{\left(\nu-(\nu-\sigma) a_{1}\right)(1-\alpha)+\eta+\alpha} \\
& v_{c}^{y}=\log \left(\frac{\varepsilon}{\varepsilon-1}\right) \frac{1-\alpha}{\left(\nu-(\nu-\sigma) a_{1}\right)(1-\alpha)+\eta+\alpha} \\
& v_{s m}^{y}=\frac{(\nu-\sigma)\left(1-a_{1}\right)(1-\alpha)}{\left(\left(\nu-(\nu-\sigma) a_{1}\right)(1-\alpha)+\eta+\alpha\right)(1-\nu)} \\
& v_{y+1}^{m}=-\frac{a_{2}}{\nu}\left(\nu-(\nu-\sigma) a_{1}\right) \\
& v_{y}^{m}=1+\frac{a_{2}}{\nu}\left(\nu-(\nu-\sigma) a_{1}\right) \\
& \kappa_{x}=\left(\nu-(\nu-\sigma) a_{1}+\frac{\eta+\alpha}{1-\alpha}\right)(1-\alpha)(1-\beta \theta) \frac{(1-\theta)}{\theta(1-\alpha+\alpha \varepsilon)} \\
& \kappa_{m}=(1-\alpha)(1-\beta \theta)(\sigma-\nu)\left(1-a_{1}\right) \frac{(1-\theta)}{\theta(1-\alpha+\alpha \varepsilon)} \\
& \kappa_{r}=\frac{1}{\nu-a_{1}(\nu-\sigma)} \\
& \kappa_{m p}=\frac{(\sigma-\nu)\left(1-a_{1}\right)}{\nu-a_{1}(\nu-\sigma)} \\
& \kappa_{s p}=-\frac{1}{\nu-a_{1}(\nu-\sigma)} \\
& \kappa_{s m}=-\frac{\left(1-a_{1}\right)(\nu-\sigma)}{\left(\nu-a_{1}(\nu-\sigma)\right)(1-\nu)} \\
& \kappa_{i}=\frac{a_{2}}{\nu} \\
& \text { with } a_{1}=\frac{1}{1+(b /(1-b))^{1 / \nu}(1-\beta)^{(\nu-1) / \nu}} \text { and } a_{2}=\frac{1}{\exp (1 / \beta)-1}
\end{aligned}
$$

As we assume that households get utility from holding money, these two models include money in the utility function. The baseline model considers separability between consumption and real money balances, as is generally the case in the literature. In this case, real money balances are irrelevant in explaining the dynamics of the model, due to this separability condition. Consequently the money equation (9) becomes completely recursive from the rest of the system. In that case, money has no role to play in the equations explaining the other variables of the model (equations 6, 7, 8 and 10).

The second model introduces non-separability between consumption and real money balances in order to analyse the situation where the marginal rate of substitution between current and future consumption depends on current and future real money balances. In that case money enters explicitly in the equations that determine output (current output and its flexible-price counterpart) and inflation (equations 13, 15 and 16). This results from the fact that consumption and money being linked in the agents utility function, money enters the equations where output appears, insofar $Y_{t}=C_{t}$ at equilibrium. 


\section{Empirical results}

\subsection{Data}

In our Eurozone model, $\hat{\pi}_{t}$ is the log-linearized inflation rate measured as the yearly log difference of GDP deflator from one quarter to the same quarter of the previous year, $\hat{y}_{t}$ is the log-linearized output measured as the yearly log difference of GDP from one quarter to the same quarter of the previous year, and $\hat{\imath}_{t}$ is the short-term (3-month) nominal interest rate. These data are extracted from the Euro area Wide Model database (AWM) of Fagan et al. (2001). $\widehat{m p}_{t}$ is the log-linearized real money balances measured as the yearly log difference of real money from one quarter to the same quarter of the previous year, where real money is measured as the log difference between the money stock and the GDP Deflator. We use the M3 monetary aggregate from the OECD database. $\hat{y}_{t}^{f}$, the flexible-price output, and $\widehat{m p}_{t}^{f}$, the flexible-price real money balances are completely determined by structural shocks.

\subsection{Bayesian estimations}

We study three different crisis periods: 1990Q1 to 1993Q4, during the speculative attacks on currencies in the European Exchange Rate Mechanism (Black Wednesday crisis); 2000Q1 to 2003Q4, during the burst of the Dotcom bubble (Dot-com crisis); and 2006Q1 to 2009Q4, during the Subprime's crisis.

Calibration of the models is explained in Appendix 9.A and all the marginal densities are presented in Appendix 9.B.

Each period is of 16 quarters. For every quarter of each period we run a Bayesian estimation by using the 25 observations before each respective quarter. We thus obtain 16 Bayesian estimations for each period of analysis.

Our purpose here is not to present all these results, a very cumbersome task indeed ${ }^{1}$. What is of interest is to draw from these estimations the evolution of the micro and macro parameters, the unconditional variance decomposition of variables with respect to shocks and the forecasting performance of the two models.

\footnotetext{
${ }^{1}$ All the results can however be provided upon request.
} 


\subsection{Methodology}

The above estimations provide the values of micro and macro parameters through time. These parameters explain the dynamics of the different variables during the crises under consideration.

The estimated micro parameters on which we concentrate are the risk aversion coefficient, the Taylor rule coefficients, the measure of decreasing returns, and the probability of firms that reoptimize optimally their price every period. The other parameters are calibrated.

Several key macro-parameters of the non-separable model are also analyzed, such as: the parameter of the gap between real money balances and its flexible-price counterpart on inflation $\left(\kappa_{m}\right)$; the expected real money growth shock parameter on output $\left(\kappa_{s m}\right)$; the expected real money growth parameter on output $\left(\kappa_{m p}\right)$; the flexible-price real money parameter on flexible-price output $\left(v_{m}^{y}\right)$; and the money shock parameter on flexible-price output $\left(v_{s m}^{y}\right)$.

Other common macro-parameter of the two models are analyzed, notably the real interest rate parameter on output $\left(\kappa_{r}\right)$ and the technology shock parameter on flexible-price output $\left(v_{a}^{y}\right)$.

The successive estimations and simulations lead to variance decompositions of variables with respect to shocks. In order to study the role of each shock on the variance of the variables, we analyze the unconditional variance decomposition of output, inflation, interest rate and real money balances with respect to the preference shock $\left(\varepsilon_{t}^{P}\right)$, the technology shock $\left(\varepsilon_{t}^{a}\right)$, the money shock $\left(\varepsilon_{t}^{M}\right)$ and the interest rate shock $\left(\varepsilon_{t}^{i}\right)$. This analysis reveals the potential role of money and monetary policy, but also of technology and preferences on the dynamics of the system.

Finally, after each estimation, we run out-of-sample (over four periods, i.e. one year) DSGE forecasts in order to compare the forecasting performance of the two models. To conduct these forecasting exercises, we simulate our estimated models from a given state and analyze the trajectories of the forecasted endogenous variables for the baseline model and the non-separable money model. These forecasting exercises are done following the Metropolis-Hastings iterations, on the basis of the posterior means of each estimated variables. The main objective of this exercise is to compare the forecasts to the actual data. Then, a comparison of the two models' forecasts is provided by the calculation of the Root Mean Square Deviation (RMSD).

To illustrate the prediction performance of our DSGE models, we perform sixteen out-of-sample prediction over the three crises.

In order to evaluate the forecasting performances, the models are re- 
estimated every quarter, by taking twenty five observations before a given quarter, and this for each of the sixteen quarters of a crisis period. For each four out-of-sample forecast, we calculate the sum of the corresponding RMSD values, and compare these values between the two models.

\section{European Exchange Rate Mechanism crisis}

\subsection{Parameters analysis}

The results of the Bayesian estimates are summarized in the following figures, where each date corresponds to the end of each estimation sample (of twenty five observations).

In all the figures, the dashed line refers to the non-separable model while the solid line refers to the baseline model.
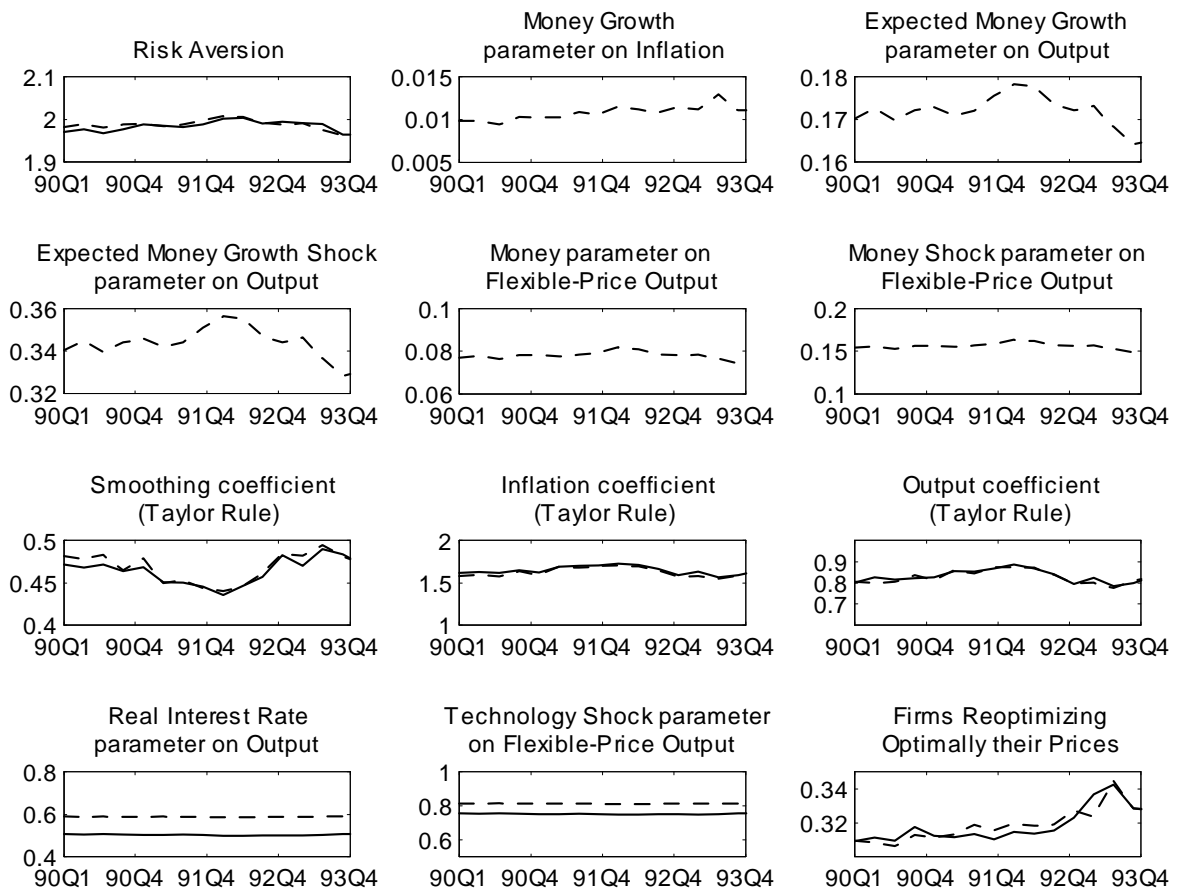

Figure 1: Parameters variations (1990Q1 to 1993Q4)

Figure 1 shows the evolution of micro and macro-parameters. Even though these values do not change much in absolute terms, such small vari- 
ations may be enough to explain changes in the dynamic impact of shocks on variables and on the overall interdependent system of equations over time.

A closer look at the value of these parameters shows that risk aversion, the expected money growth parameter on output, the expected money growth shock parameter on output, and the inflation and output coefficients of the Taylor rule, display a small peak in 1992Q1.

Moreover, after the Black Wednesday crisis (i.e. after 1993Q1), more firms choose to reoptimize optimally their prices. During the period, the real interest rate parameter on output and the technology shock parameter on flexible-price output are rather constant.

There does not exist wide differences between both models as to the dynamics of the parameters estimations. 


\subsection{Variance decomposition}

For each Bayesian estimation of the two models, we compute the unconditional variance decomposition of the variables. This variance decomposition gives interesting information as to the role of each shock.
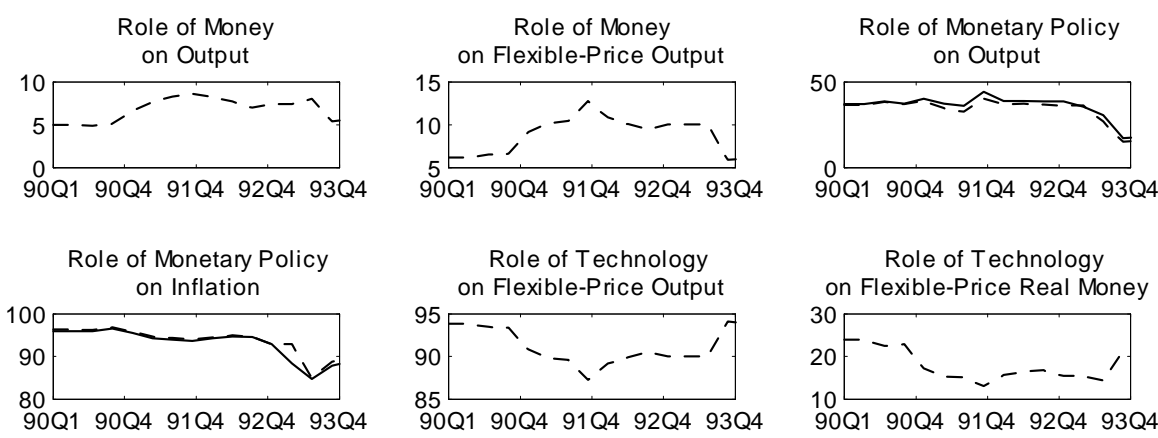

Role of Technology on Flexible-Price Real Money
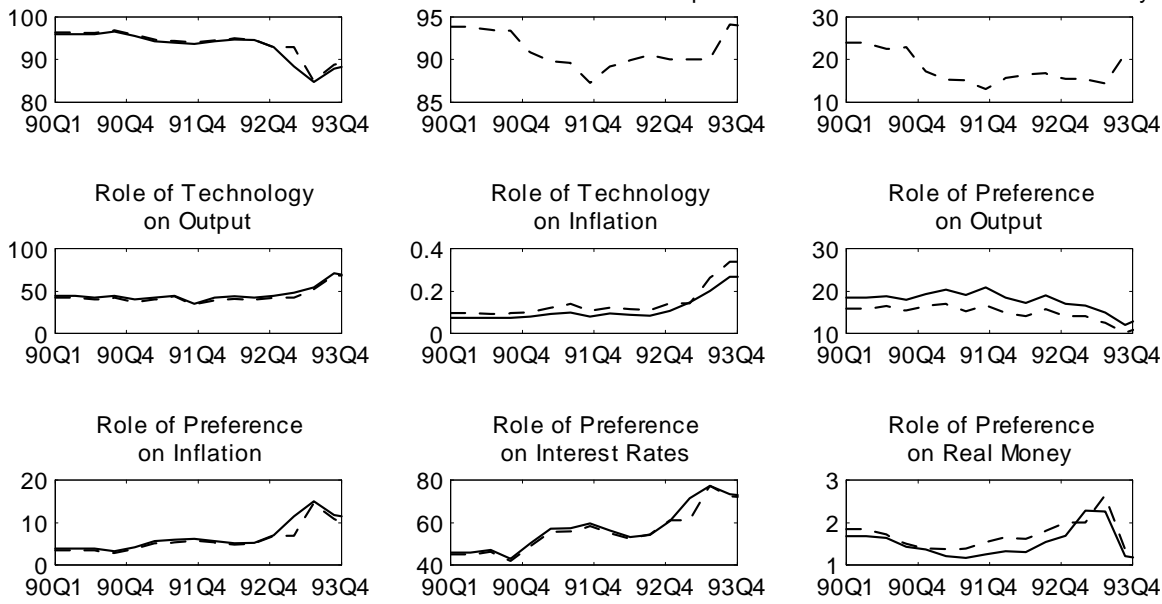

Figure 2: Variance decomposition in percent (1990Q1 to 1993Q4)

Figure 2 shows that money plays a non-negligible role in output variations during the European Monetary System crisis. This role reaches its maximum in 1991Q4, where about $10 \%$ of the output's variance is explained by the money shock. This result is mainly due to the variation in the expected money growth parameter and in the expected money growth shock parameter on output (see Figure 1). After and before the crisis, money seems to play a less significant role. We don't present the role of money on inflation as far as it is almost nil (less than 0.1\%).

Figure 2 also shows that the role of monetary policy on output and inflation decreases by the end of the crisis, and that technology plays a lower role during the crisis, especially as far as flexible-price output is concerned.

Shocks on output from money, monetary policy, technology and prefer- 
ences explain $100 \%$ of the output variance. The role of technology increases after 1993Q1, at the same time as the role of monetary policy, of money and of preferences decrease.

The role of preferences on interest rates and inflation increases after the crisis (this role is negligible on real money balances) whereas it decreases on output.

\subsection{Forecasting performances}

From each Bayesian estimation, we simulate the out-of-sample forecasts of output and inflation over the next four periods (one year).

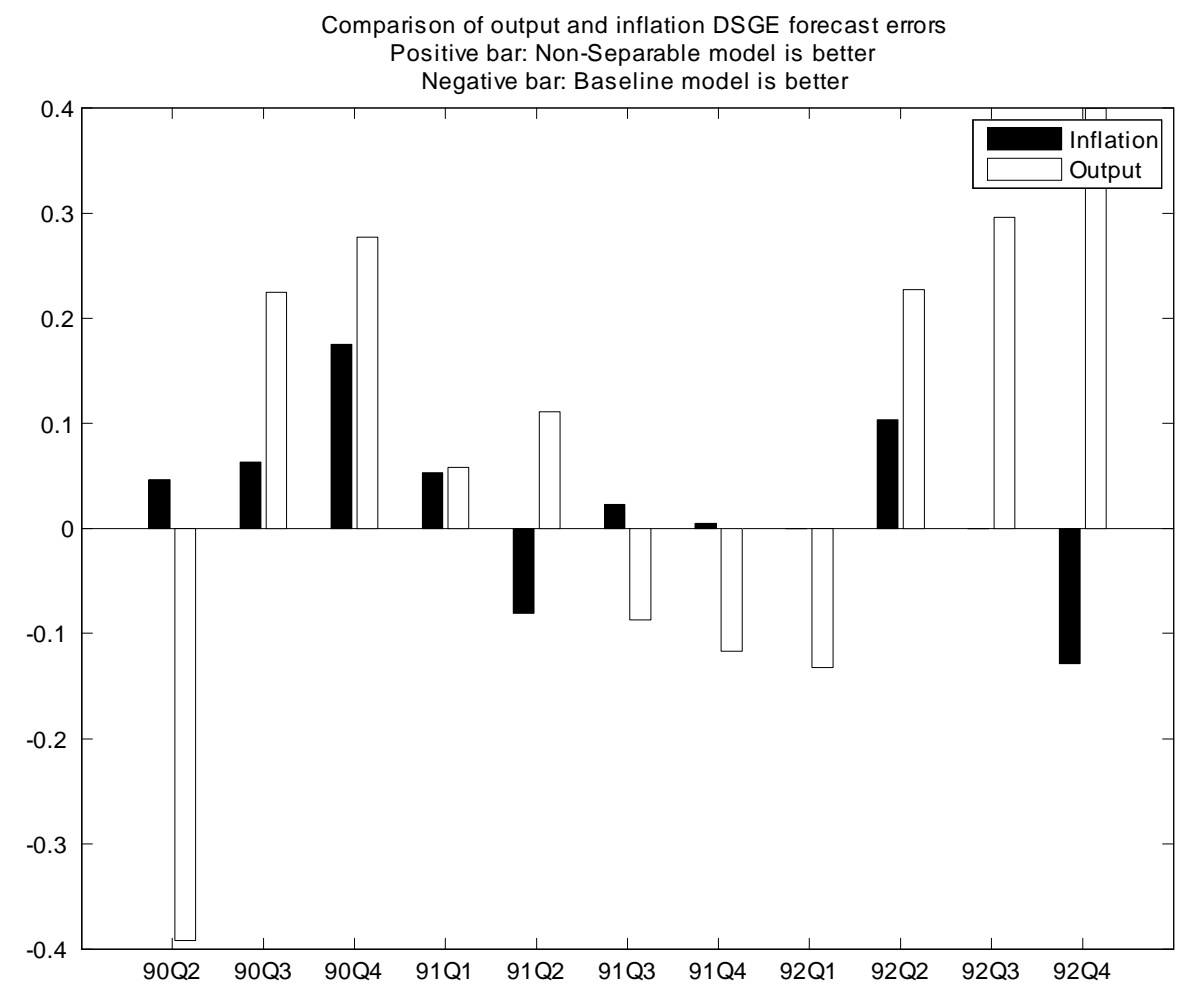

Figure 3: Out-of-sample forecasting errors (DSGE Forecast)

A negative number implies that the non-separable money model's RMSD is higher than the baseline model's RMSD. In that case the baseline model has better forecasting performances than the non-separable model. Figure 3 shows that the model with non-separability demonstrates a better predictive 
power for output dynamics than the baseline model between 1990Q2 and 1991Q2 and during the speculative attacks on currencies in the European Exchange Rate Mechanism between 1992Q2 and 1992Q4.

From 1990Q1 to 1991Q2, the non-separable model has a better predictive power of inflation dynamics whereas the performances are mixed during the other periods.

\subsection{Interpretation}

Black Wednesday refers to the events of 16 September 1992 when the British Conservative government withdrawed the pound sterling from the European Exchange Rate Mechanism. Yet other crises occurred during our period of analysis.

From 1990Q2 to 1991Q2, an oil crisis followed the first Gulf war². From 1992Q2 to 1992Q4, the Russian crisis $^{3}$ and the French Real Estate crisis ${ }^{4}$ could have affected the Eurozone business cycle. Figure 1 shows that during this period several parameters reach a peak.

Figure 2 shows that from 1990Q3 on the impact of money on (current and flexible-price) output increases and remains at a higher level until about the end of the period. This impact is higher than what Ireland (2004) and Andrés, López-Salido, and Vallés (2006) found. The reason for this result seems mainly due to the variation of the expected money growth parameter and of the expected money growth shock parameter on output (Figure 1).

Figure 2 also indicates that, since 1992Q4, the beginning of the ERM crisis, the role of monetary policy on output and inflation has decreased and reached its lowest level at the top of the crisis (1993Q3).

The RMSD errors comparison (Figure 3) and the business cycles of the period are anticorrelated, showing that the non-separable model has a better predictive power of output than the baseline model during the lower part of the cycle. Moreover, during the Black Wednesday period (after 1992Q2), and during the other crises mentioned above (from 1990Q2 to 1991Q2), the non-separable model demonstrates a better predictive power of output than over the other periods.

These findings confirm the predictive abilities of the non-separable model during crisis periods, whereby the role of money on output increases.

\footnotetext{
${ }^{2}$ The 1990 oil price spike occurred in response to the Iraqi invasion of Kuwait on August 2, 1990. The war lasted until February 28, 1991.

${ }^{3}$ The constitutional crisis of 1993 was a political stand-off between the Russian president and the Russian parliament that was resolved by using military force.

${ }^{4}$ From 1992 to 1996, real estate prices declined up to $40 \%$.
} 


\section{Dot-com crisis}

\subsection{Parameters analysis}

The following figure presents the Bayesian estimation results of micro and macro parameters through time during the Dot-com crisis (2000Q1 to 2003Q4).
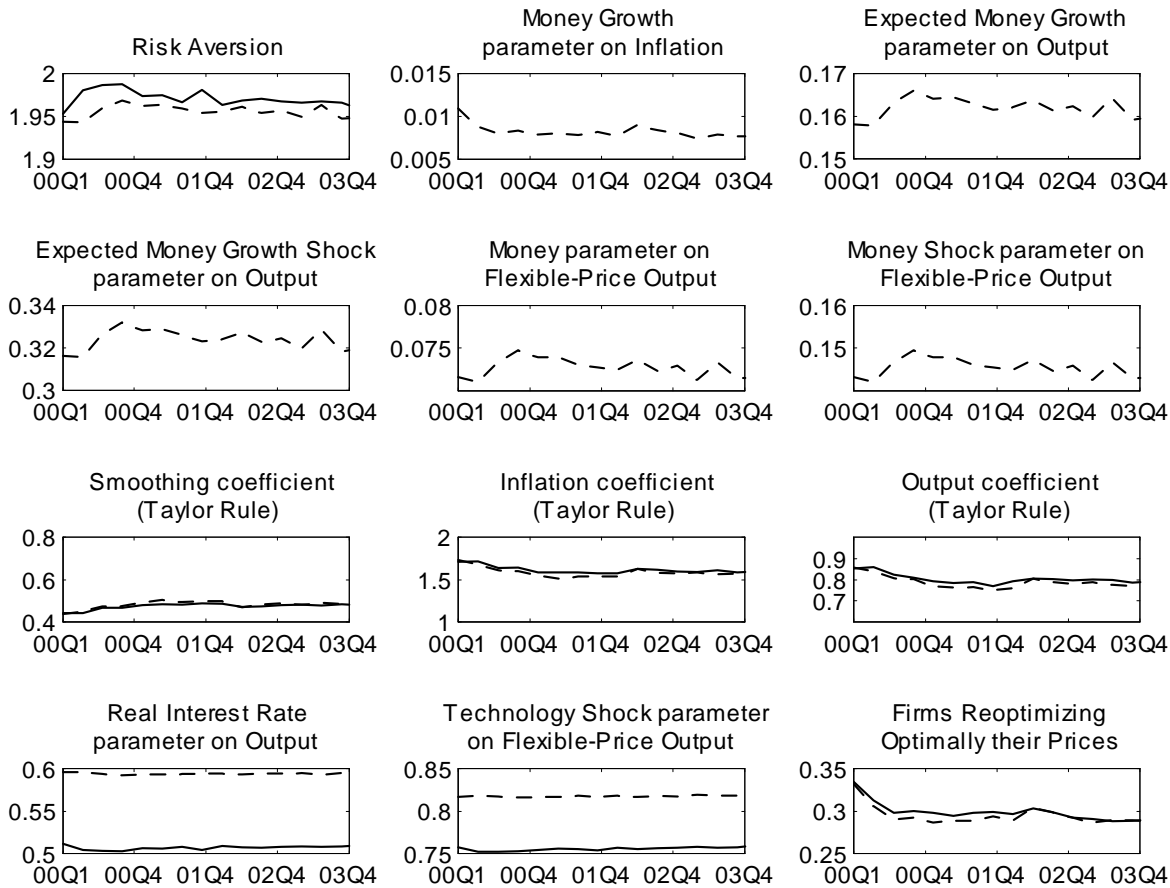

Figure 4: Parameters variations (2000Q1 to 2003Q4)

Figure 4 shows that if the risk aversion parameter does not change much over the period, at least in absolute terms, it gets to a peak whenever troubles happen: around 2000Q4 when the internet bubble started to burst and in 2001Q3 around the time of the 9/11 terrorist attacks.

In absolute terms the other parameters do not change much either even though the money related parameters on output (current and its flexibleprice counterpart) show also a peak in 2000Q4 and remain at a somewhat higher level over the rest of the period. 


\subsection{Variance decomposition}

The following figure presents the variance decomposition of variables through time during the Dot-com crisis (2000Q1 to 2003Q4).
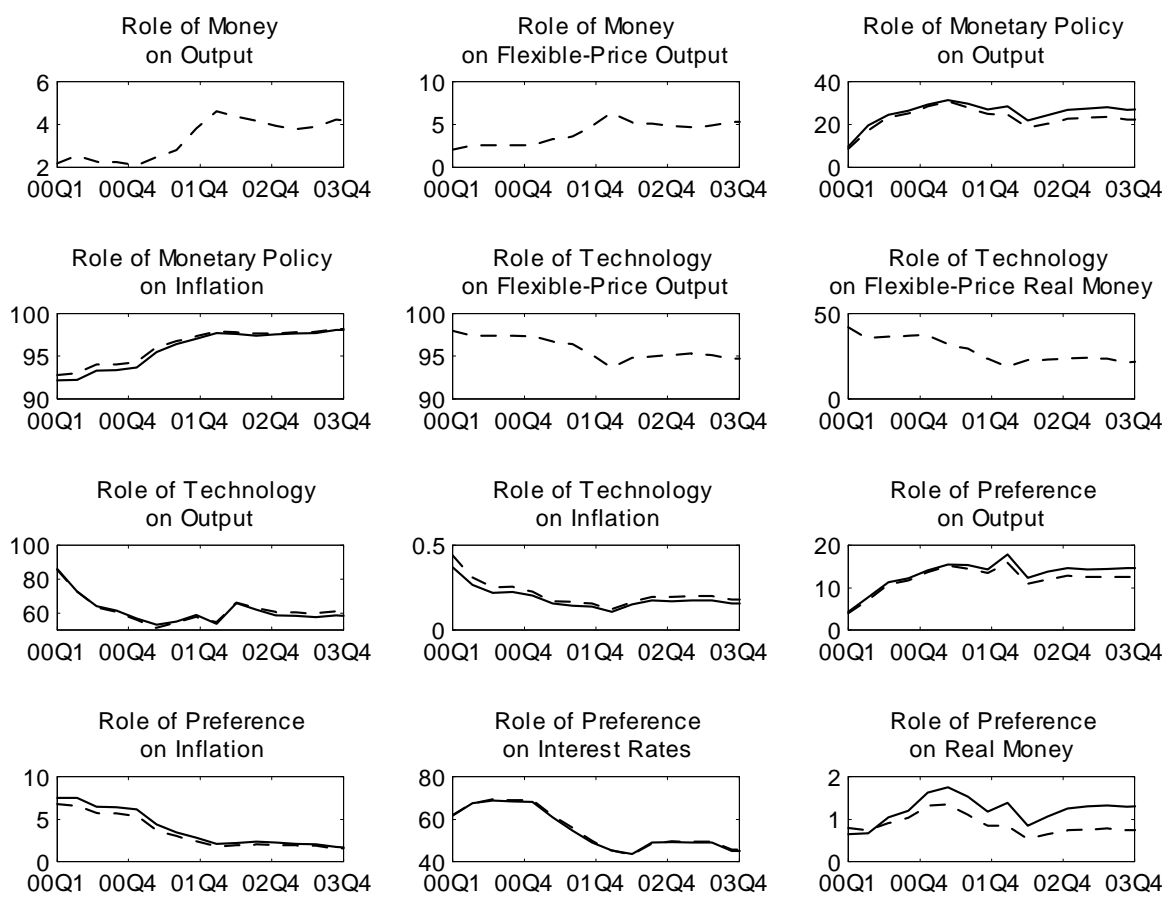

Figure 5: Variance decomposition in percent (2000Q1 to 2003Q4)

Figure 5 shows that since 2001Q2, the role of money on output and on flexible-price output has increased. However, this role is rather minor. As in the ERM crisis, the role of money on inflation is negligible (not presented).

After the bubble bursting, i.e. mainly after 2000Q4, the role of monetary policy on inflation increases whereas the change is not visible on output.

As in Figure 2, Figure 5 also shows that technology plays a lower role in explaining current and flexible-price outputs during the crisis.

\subsection{Forecasting performances}

Figure 6 shows that the non-separable model is significantly better than the baseline model over the whole period (except in 2000Q2), in terms of predicting output. In terms of inflation, it is difficult to discriminate which 


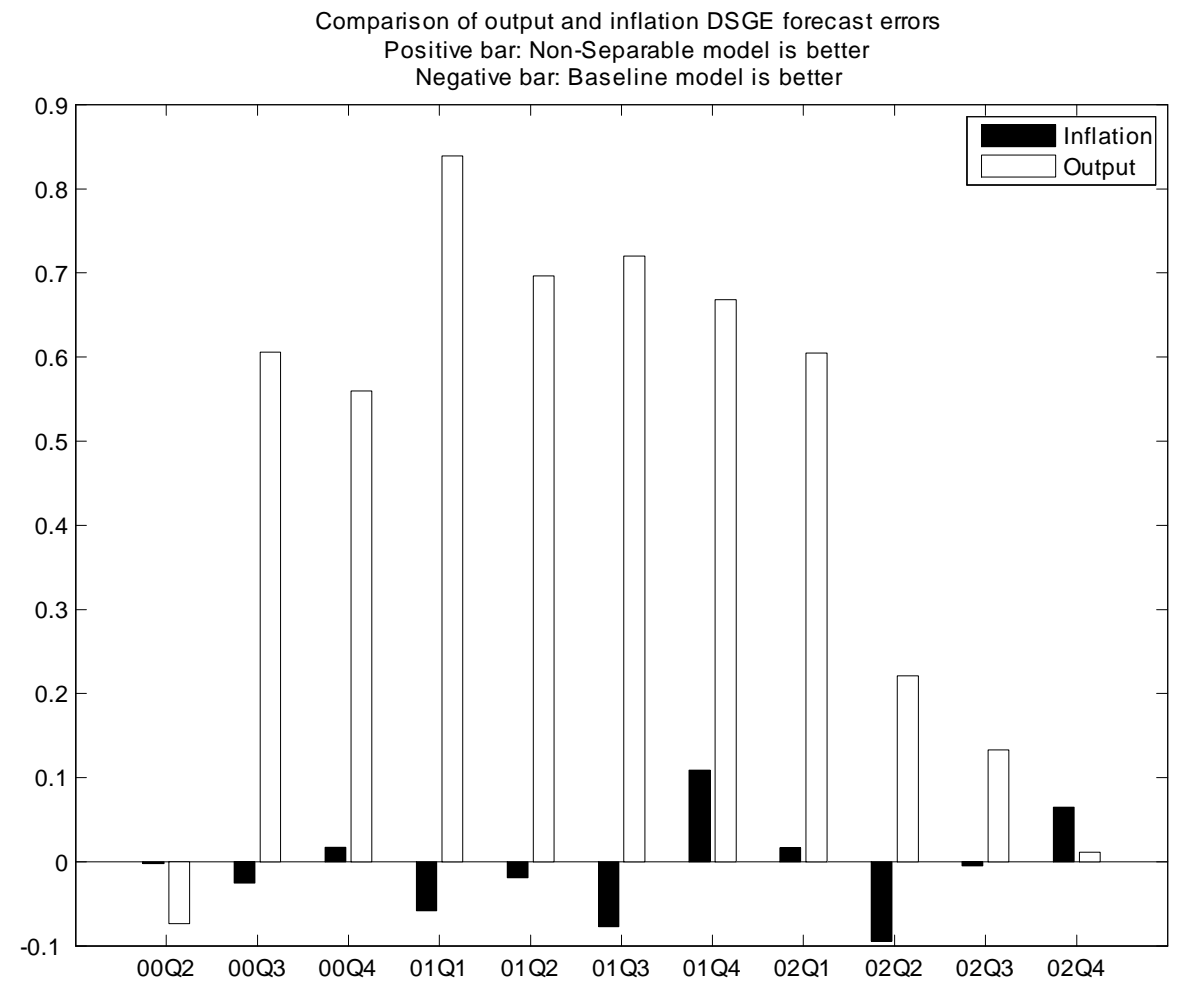

Figure 6: Out-of-sample forecasting errors (DSGE Forecast)

model is the best (the RMSD differences of the inflation forecasts are rather small).

\subsection{Interpretation}

The bursting of the Dot-com bubble occurs in the Eurozone approximately two quarters (2000Q4) after the United States (2000Q2). Even if the role of money on output before 2001Q4 is small, it increases after this date. Between 2001Q1 and 2001Q4, the core of the Dot-com crisis, the role of technology on output reaches its minimum. This result confirms the decreasing role of technology on output dynamics during this crisis.

The percentage of the variance of output and flexible price-output explained by the money shock is small and close to the value found by Andrés, López-Salido, and Vallés (2006). Moreover, although the Taylor rule coefficients are rather constant (Figure 4), the role of monetary policy on output 
and inflation has increased since the beginning of the period (Figure 5).

The clear dominance of the non-separable model over the baseline model in terms of output forecasting errors confirms the predictive abilities of the non-separable model during crisis periods.

\section{Subprime crisis}

\subsection{Parameters analysis}

The following figures present the Bayesian estimation results through time over the subprime crisis (2006Q1 to 2009Q4).
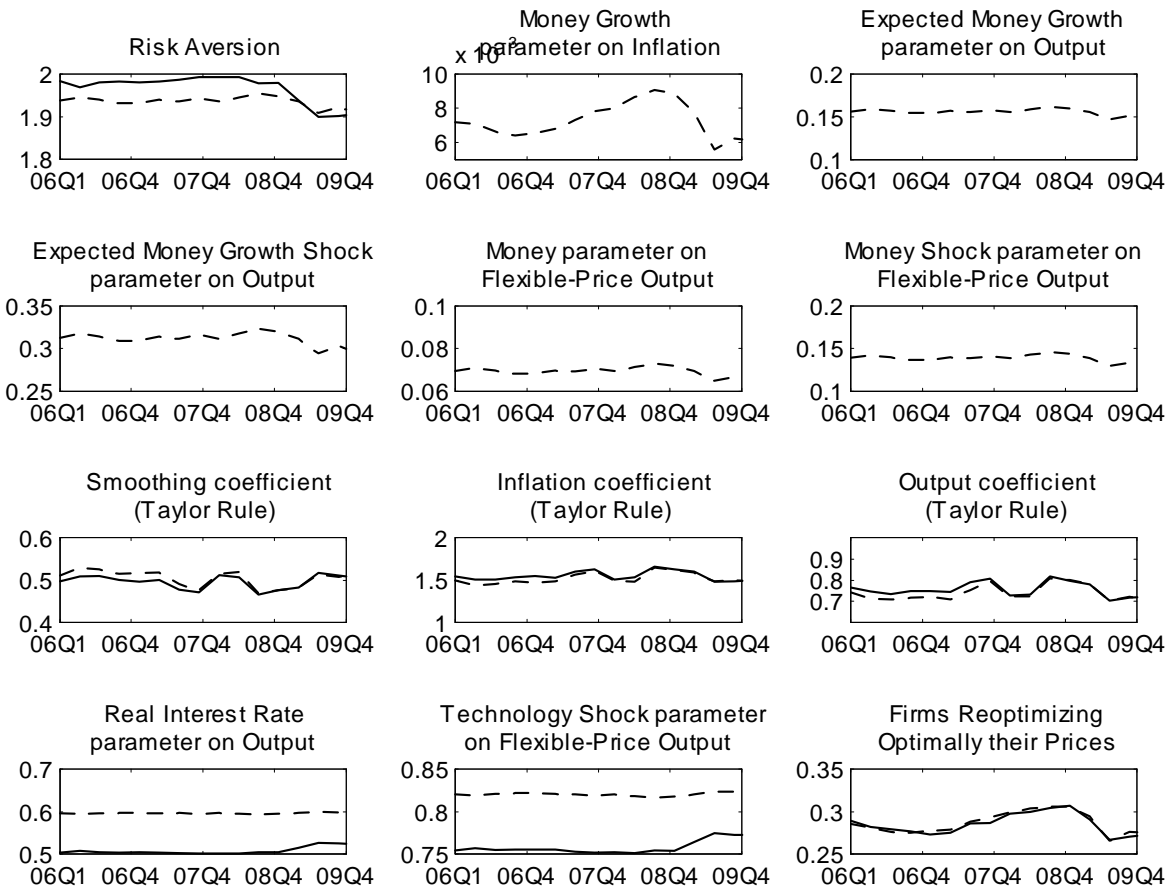

Figure 7: Parameters variations (2006Q1 to 2009Q4)

Figure 7 shows that after the Lehman Brother's bankruptcy (2008Q4), the risk aversion parameter decreases, whatever the model.

The expected money growth shock parameter on output reaches its maximum in 2008Q3 whereas the other parameters of output and flexible-price output remain rather stable during the period. 
The money growth parameter on inflation also reaches its maximum in 2008Q3, but its variations are not large.

Even if the variations are small, the weights on inflation and on output in the Taylor rule reach a peak in 2007Q4 and in 2008Q4, while the smoothing parameter reaches on the contrary its lowest values.

\subsection{Variance decomposition}
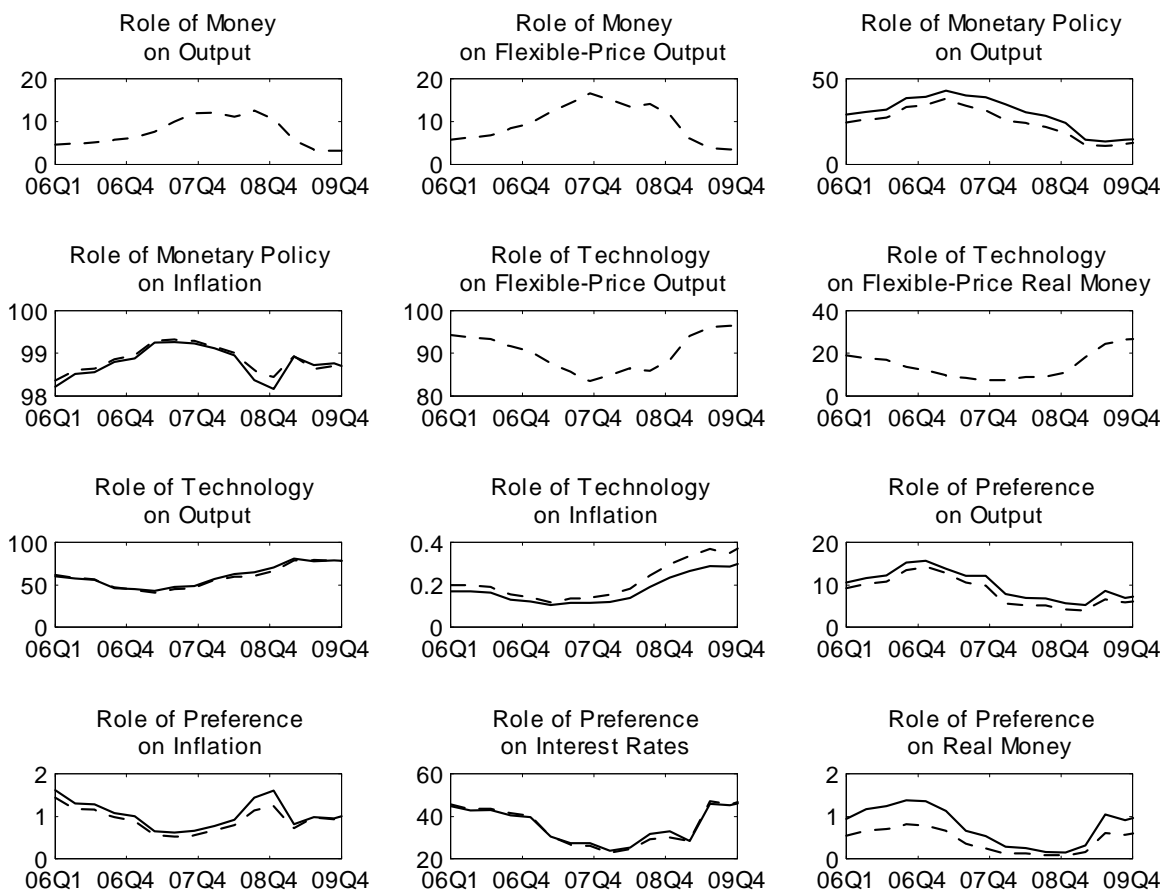

Figure 8: Variance decomposition in percent (2006Q1 to 2009Q4)

Figure 8 shows that the role of the money shock on output increases in 2007 and reaches a peak in 2008Q2. This shock explains around 5\% of the variance in 2006Q4, whereas the percentage increases to $12 \%$ in 2008Q2, and goes back to 4\% in 2009Q4. The impact of money on the flexible-price output follows about the same dynamic path.

As in the other crises, and because it is insignificant, we don't represent the role of money on inflation.

It is interesting to notice that the impact of monetary policy on output 
and inflation follows the same pattern as with the money shock, but it gets its higher level a little earlier (2007Q1). Monetary policy explains most of the inflation variance, with a maximum in 2007Q3.

Figure 8 also shows that the role of preferences on output, interest rates, and real money balances is lower during the crisis than before and after the crisis. Technology has a lower role in explaining flexible-price output variance at the beginning of the crisis than before and after the crisis. The role of technology on output and inflation grows up significantly after the crisis.

A simultaneous analysis of all the shocks indicates that the increasing role of money on output is associated with a decline in the role of monetary policy and of preferences. These declining impacts start at the beginning of the subprime crisis.

\subsection{Forecasting performances}

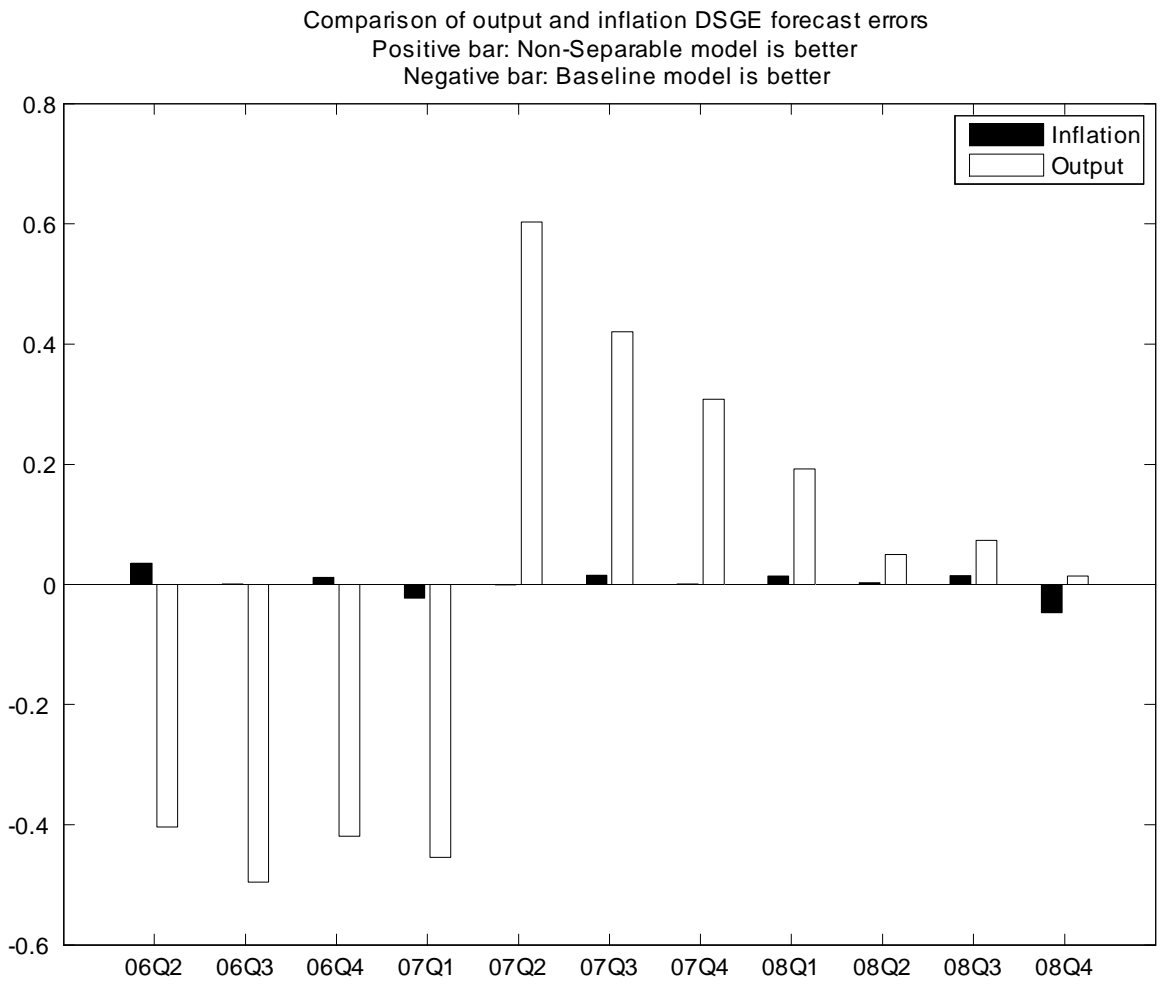

Figure 9: Out-of-sample forecasting errors (DSGE Forecast) 
Figure 9 shows that the non-separable model provides better forecasts of output than the baseline model at the core of the financial crisis (2007Q2 to 2008Q3). The inflation RMSDs are about the same over the period.

\subsection{Interpretation}

The subprime crisis can be attributed to a number of factors pervasive in both housing and credit markets, factors which emerged over a number of years. For Cecchetti (2009) and Mishkin (2010), a complete chronology of the crisis might starts in 2007Q1 when several large subprime mortgage lenders started to report losses. The real trigger of the crisis was in 2007Q3 when the French bank BNP Paribas temporarily halted redemptions from three of its funds that held assets backed by U.S. subprime mortgage debt.

As a direct consequence, credit spreads began widening, overnight interest rates in Europe shot up, and the European Central Bank immediately responded with the largest short-term liquidity injection in her nine year history. Furthermore, if the global financial crisis began in 2007 in the US, the Eurozone entered its first official recession in 2008Q3.

The Euro Group heads of states and governments and the European Central Bank (ECB) held an extraordinary summit in October 2008 to define a joint action for the Eurozone. They agreed on a bank rescue plan which would involve hundreds of billions of euros: governments would enter banks capital and guarantee interbank lending. That may explain the decrease in risk aversion after 2008Q4 (Figure 7), and the decreasing role of money on output variations after this date.

These results also suggests that at the top of the crisis, the role of money is at its highest. Contrary to Ireland (2004) and Andrés, López-Salido, and Vallés (2006), it shows that money had a significant role to play during the financial crisis.

To understand better the relationship between the role of money and financial risk, it is interesting to introduce the evolution of the interest rate spread over the period. This spread ${ }^{5}$ provides an assessment of counterparty risk from one bank lending to another, reflecting both liquidity and credit risk concerns.

As Figure 10 shows, the dynamics of the role of money on output during the crisis is positively related to the widening of the spread between the Euribor and both baselines interest rates (Bubill and BTF).

\footnotetext{
${ }^{5}$ The spread is measured as the difference between the 3-month Euribor and a short maturity bond. As an European bond does not exist, we choose the 3-month BTF (France) and the 1-Year Bubill (Germany) as short-term Treasury bills.
} 


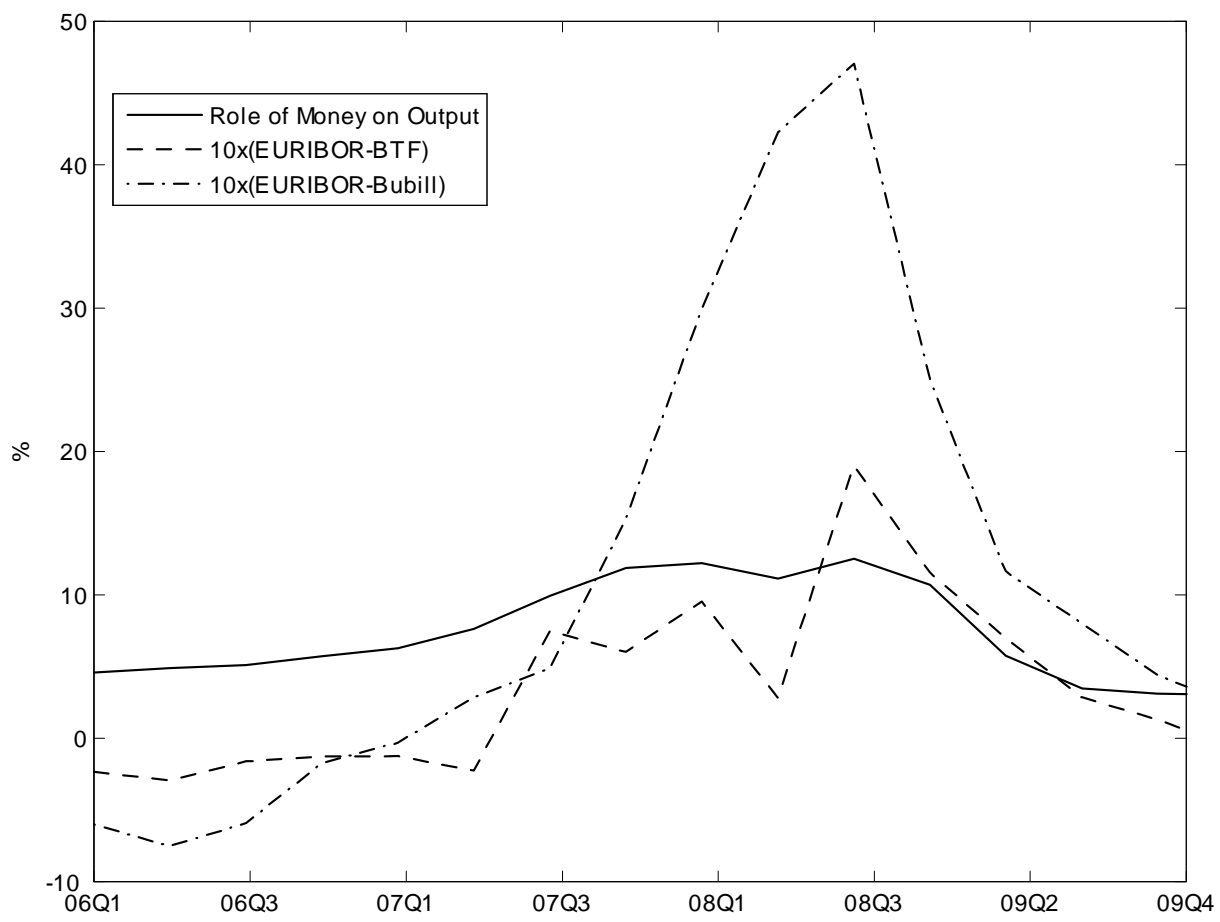

Figure 10: Comparison between the role of money on output (variance decomposition) and the spreads between the Bubill/BTF and the Euribor

In the same vein, Figure 11 shows that the role of monetary policy decreases as the same time as the spread increases. If the role of monetary policy is at its maximum before the crisis starts (2007Q2), it diminishes quickly after: its impact on output is divided by four, declining from $40 \%$ to about $10 \%$.

The RMSD analysis also reveals that the DSGE model with non-separable utility fares quite well against the baseline model after 2007Q2, that is after the beginning of the Global Financial Crisis (GFC). Given the stability of the macro parameters (Figure 7), it can be inferred that this increasing role is mainly due to micro parameters variations such as variations of the risk aversion parameter $(\sigma)$ or of the percentage of firms reoptimizing their prices $(1-\theta)$. 


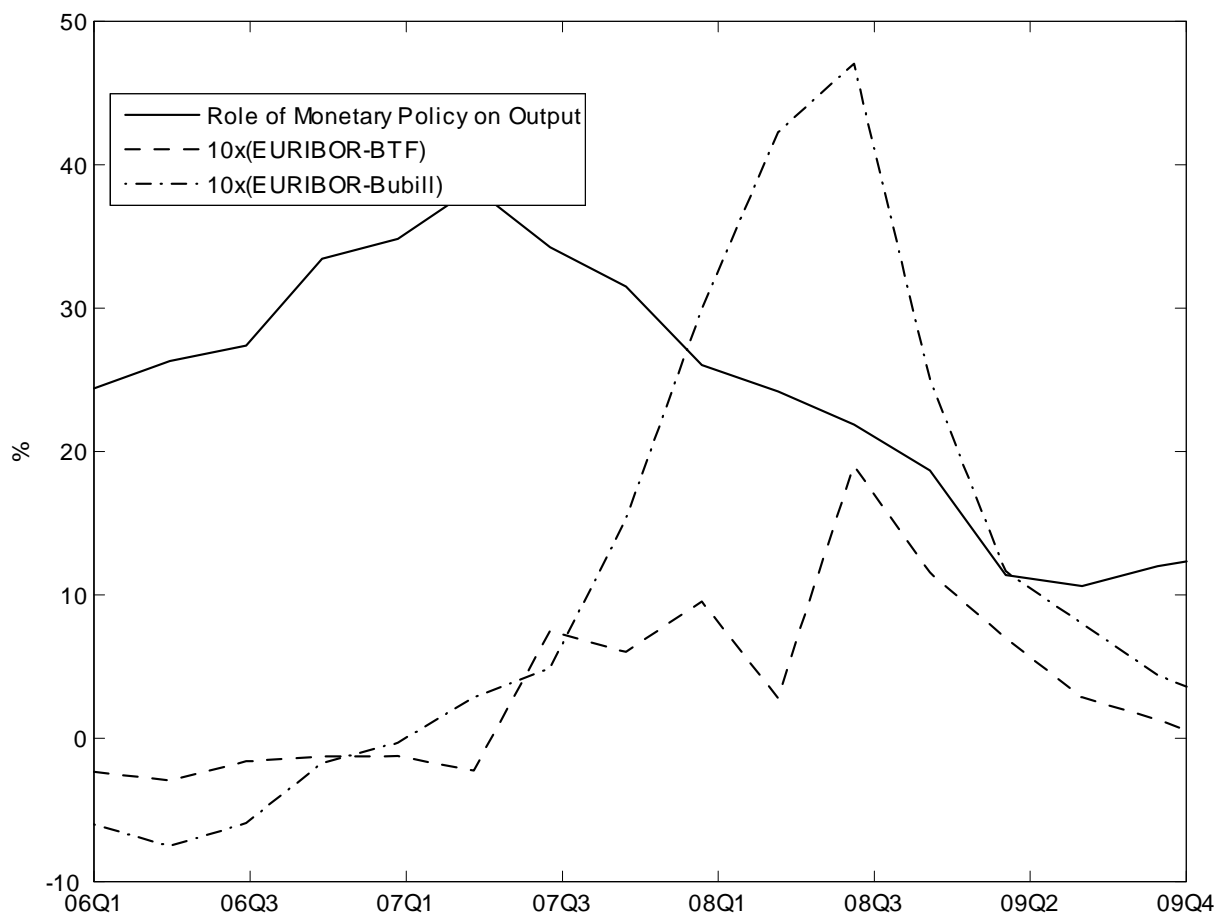

Figure 11: Comparison between the role of monetry policy on output and the spreads between Bubill/BTF and Euribor

\section{A comparison of the three crises}

To better assess the relationship between money, monetary policy and output during the crises under consideration, and to better understand the respective role of the shocks, a comparison of variance decompositions between the different crises is useful. For the Subprime crisis and the European Exchange Rate Mechanism crisis, money plays a more significant role on output (more than 10\%) than during the Dot-com crisis (less than 4\%). These values must be compared to Ireland (2004), Andrés, López-Salido, and Vallés (2006) and Andrés, López-Salido, and Nelson (2009), which found that money's role in the business cycle appears limited. Money plays a stronger role during the Subprime crisis $(12.5 \%)$ than during the other crises. Similarly, money plays a stronger role on flexible-price output at the beginning of the Subprime crisis (16.5\%) than during the other crises, where the money shock contribution to the flexible-price output variance is about $13 \%$ in 
1992Q1 (beginning of the ERM crisis) and about 5\% in 2002Q1 (Dot-com crisis).

The period where the role of technology on flexible-price output is at its minimum seems to be at the peak of the crisis, and this for the three crises. This result means probably that technology has a lower role to play in explaining flexible-price output during crisis than during more normal periods where flexible-price output variability is completely determined by the technology shock. The decline of the role of technology on flexible-price output is furthermore associated with a corresponding increase of the role of money on flexible-price output.

Preferences seems to play a role on all variables only during the subprime crisis, and this for both models. The preference shock has a significant impact on output and interest rates before the Subprime crisis, yet this impact diminishes during the crisis (divided by almost two). This behavior may be due to the importance of the role of money, especially during the Global Financial Crisis.

It is also interesting to note that over the three crisis, the impact of monetary policy on output is different. It is around $35 \%$ at the top of the Dot-com crisis whereas it reaches almost $50 \%$ at the top of the ERM and of the Subprime crisis.

The impact of monetary policy on inflation is also different over the three crises. It appears to be lower during the ERM crisis and the Dot-com crisis than during the Subprime crisis.

Finally, in terms of forecasting, the non-separable model performs generally better than the separable one, as shown in Figure 3, 6 and 9.

\section{Conclusion}

The goal of this paper was to study the role of money and monetary policy during crises periods. To achieve this goal, we compared the performance of two DSGE models, one baseline model with separable preferences, as in Galí (2008), and one with non-separable preferences between consumption and real money balances, as in Benchimol and Fourçans (2012); the study is carried over three crisis periods: European ERM crisis (1992), Dot-com crisis (2001) and Subprime crisis (2007).

We tested the two models by using successive Bayesian estimations, so as to obtain empirical estimates of the evolution of parameters, variance decomposition and forecasting performances of both models over the three crises. Our analysis shows that the role of money on output variations 
increases during crises. Yet this role was higher during the ERM and the Subprime crises than during the Dot-com crisis. It also demonstrates that the model with non-separable preferences provides better forecasts of output than with the baseline model over these crisis periods.

Moreover, our results show that the impact of monetary policy on output variability diminishes significantly during the Subprime crisis, at the same time as the impact of money increases. Inflation does not seem to be affected directly by money variables, it is mainly explained by monetary policy over the three crises.

Our findings support the view that New Keynesian DSGE models with non-separability between consumption and real money balances should be preferred to separable models, as far as macroeconomic forecasting is concerned, at least during crisis periods.

Our results provide also interesting clues regarding the structural dynamics of the economy that may help inform central banks, markets and policy regulators. For example, the more significant role played by real money balances than generally expected during financial crises.

All in all, our analysis has highlighted the importance of money during crises, and showed that the hypothesis of non-separability between money and consumption leads to better forecast during these periods than when money and consumption are taken as separable.

\section{Appendix}

\section{A Calibration}

We calibrate all parameters, excepted shocks' parameters ( $\rho_{k}$ and $\sigma_{k}$ for $k=$ $\{p, m, i, a\})$, the risk aversion parameter $(\sigma)$, the price adjustment parameter $(\theta)$, the decreasing return parameter $(\alpha)$ of the production function and the Taylor rule's parameters $\left(\lambda_{i}, \lambda_{\pi}, \lambda_{x}\right)$. The monetary policy rule is an ad-hoc reaction function and completely dependent on the monetary authority.

Following standard conventions, we calibrate beta distributions for parameters that fall between zero and one, inverted gamma distributions for parameters that need to be constrained to be greater than zero, and normal distributions in other cases.

The calibration of $\sigma$ is inspired by Rabanal and Rubio-Ramirez (2005) and by Casares (2007). They choose, respectively, a risk aversion parameter of 2.5 and 1.5. In line with these values, we consider that $\sigma=2$ corresponds to a standard risk aversion. We adopt the same priors in both models with 
the same risk aversion calibration.

As in Smets and Wouters (2007), the standard errors of the innovations are assumed to follow inverse gamma distributions and we choose a beta distribution for shock persistence parameters (as well as for the backward component of the Taylor rule) that should be lesser than one.

The calibration of $\alpha, \beta, \theta, \eta$, and $\varepsilon$ comes from Galí (2008) and Casares (2007). The smoothed Taylor rule $\left(\lambda_{i}, \lambda_{\pi}\right.$, and $\left.\lambda_{x}\right)$ is calibrated following Gerlach-Kristen (2003), analogue priors as those used by Smets and Wouters (2003). In order to take into consideration possible changes in the behavior of the central bank, we assign a higher standard error for the Taylor rule's coefficients. $v$ (the non-separability parameter) must be greater than one. $\kappa_{i}$ (equation 17) must be greater than one as far as this parameter depends on the elasticity of substitution of money with respect to the cost of holding money balances, as explained in Söderström (2005); while still informative, this prior distribution is dispersed enough to allow for a wide range of possible and realistic values to be considered (i.e. $\sigma>v>1$ ).

The calibration of the shock persistence parameters and the standard errors of the innovations follows Fève, Matheron, and Sahuc (2010), where a much lower mean is adopted for $\rho_{a}$. All the standard errors of shocks are assumed to be distributed according to inverted Gamma distributions, with prior means of 0.02 . The latter law ensures that these parameters have a positive support. The autoregressive parameters are all assumed to follow Beta distributions. Except for technology shocks, all these distributions are centered around 0.75 . We take a common standard error of 0.1 for the shock persistence parameters, as in Smets and Wouters (2003). 
Table 1: Calibration for the two models Priors

\begin{tabular}{cccc}
\hline & & & \\
$\alpha$ & beta & Mean & Std. \\
$\theta$ & beta & 0.33 & 0.05 \\
$\sigma$ & normal & 2.00 & 0.05 \\
$\beta$ & calibrated & 0.99 & \\
$v$ & calibrated & 1.50 & \\
$b$ & calibrated & 0.25 & \\
$\chi$ & calibrated & 0.05 & \\
$\gamma$ & calibrated & 0.05 & \\
$\eta$ & calibrated & 1.00 & \\
$\varepsilon$ & calibrated & 6.00 & \\
$\lambda_{i}$ & beta & 0.50 & 0.10 \\
$\lambda_{\pi}$ & normal & 3.00 & 0.20 \\
$\lambda_{x}$ & normal & 1.50 & 0.20 \\
$\rho_{a}$ & beta & 0.75 & 0.10 \\
$\rho_{i}$ & beta & 0.75 & 0.10 \\
$\rho_{p}$ & beta & 0.75 & 0.10 \\
$\rho_{m}$ & beta & 0.75 & 0.10 \\
$\sigma_{a}$ & invgamma & 0.02 & 2.00 \\
$\sigma_{i}$ & invgamma & 0.02 & 2.00 \\
$\sigma_{P}$ & invgamma & 0.02 & 2.00 \\
$\sigma_{M}$ & invgamma & 0.02 & 2.00
\end{tabular}




\section{B Marginal densities}

In what follows, we present all the marginal densities of our estimates. The dashed line refers to the non-separable model while the solid line refer to the baseline model.
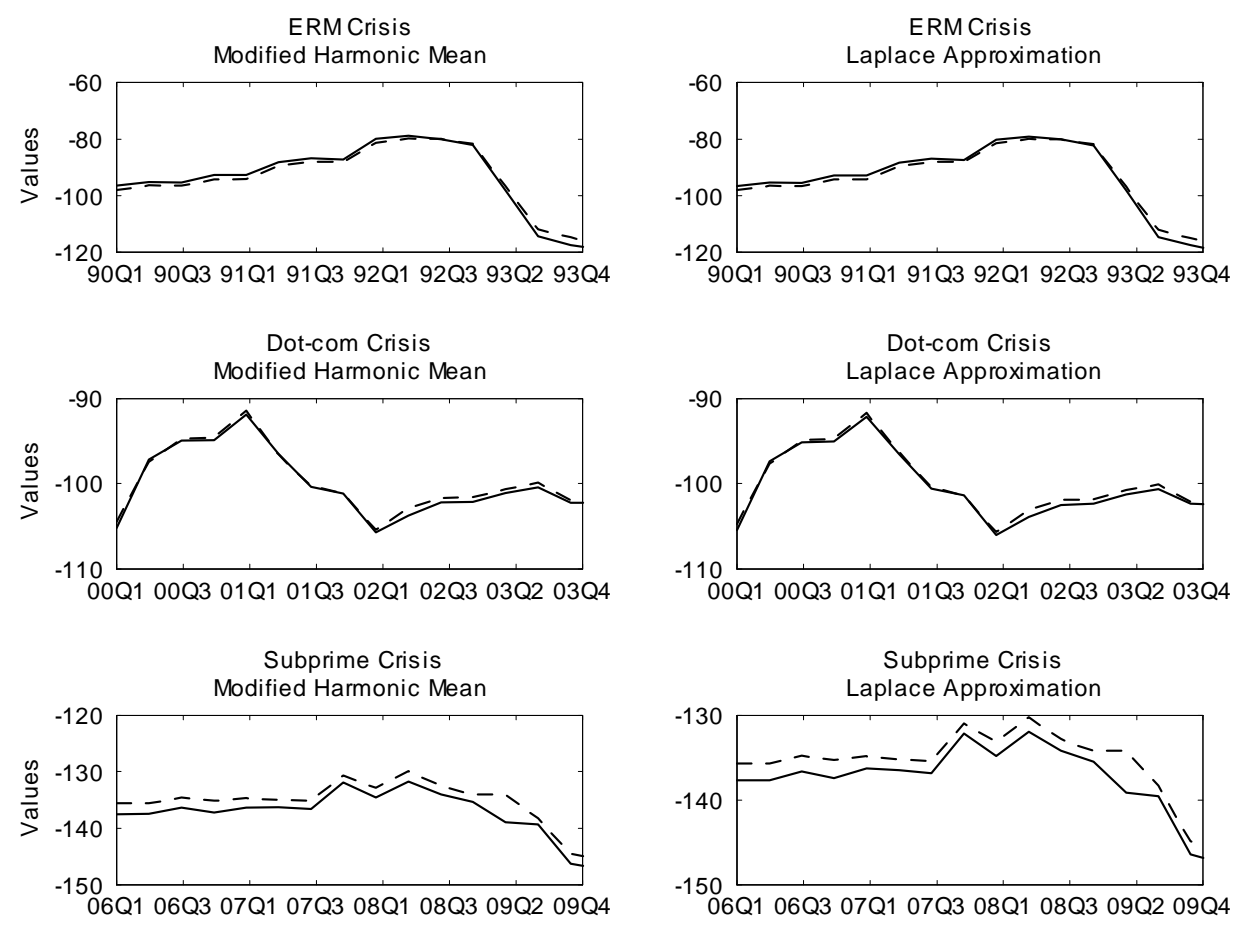

For the three crises, both models have approximately the same log marginal densities.

\section{References}

Adolfson, M., Laseen, S., Lindé, J., and Villani, M., 2007. Bayesian estimation of an open economy DSGE model with incomplete pass-through. Journal of International Economics 72(2), 481-511.

Adolfson, M., Laseen, S., Lindé, J., and Villani, M., 2008. Evaluating an estimated new Keynesian small open economy model. Journal of Economic Dynamics and Control 32(8), 2690-2721. 
An, S., and Schorfheide, F., 2007. Bayesian analysis of DSGE models. Econometric Reviews 26(2-4), 113-172.

Andrés, J., López-Salido, J.D., and Nelson, E., 2009. Money and the natural rate of interest: Structural estimates for the United States and the Euro area. Journal of Economic Dynamics and Control 33(3), 758-776.

Andrés, J., López-Salido, J.D., and Vallés, J., 2006. Money in an estimated business cycle model of the Euro area. The Economic Journal 116(511), 457-477.

Benchimol, J., and Fourçans, A., 2012. Money and risk in a DSGE framework: A Bayesian application to the Eurozone. Journal of Macroeconomics, ISSN 0164-0704, 10.1016/j.jmacro.2011.10.003.

Blinder, A.S., 1997. Is There a Core of Practical Macroeconomics That We Should All Believe?. American Economic Review 87(2), 240-43.

Casares, M., 2007. Monetary policy rules in a new Keynesian Euro area model. Journal of Money, Credit and Banking 39(4), 875-900.

Calvo, G.A., 1983. Staggered prices in a utility-maximizing framework. Journal of Monetary Economics 12(3), 383-398.

Cecchetti, S.G., 2009. Crisis and responses: The Federal Reserve in the early stages of the financial crisis. Journal of Economic Perspectives 23(1), 51-75.

Christiano, L.J., Trabandt, M., and Walentin, K., 2010. DSGE Models for Monetary Policy Analysis. NBER Working Papers \#16074.

Diebold, F.X., 1998. The Past, Present, and Future of Macroeconomic Forecasting. Journal of Economic Perspectives 12(2), 175-92.

Edge, R.M., and Gürkaynak, R.S., 2010. How useful are estimated DSGE model forecasts for central bankers ? Brookings Papers on Economic Activity, Economic Studies Program, The Brookings Institution 41(2), 209-259.

Edge, R.M., Kiley, M.T., and Laforte, J.P., 2010. A comparison of forecast performance between Federal Reserve staff forecasts, simple reducedform models, and a DSGE model. Journal of Applied Econometrics, 25(4), 720-754. 
Fagan, G., Henry, J., and Mestre, R., 2001. An area-wide model (AWM) for the Euro area. European Central Bank Working Paper No. 42.

Fernandez-Villaverde, J., and Rubio-Ramirez, J.F., 2004. Comparing dynamic equilibrium models to data: a Bayesian approach. Journal of Econometrics 123(1), 153-187.

Fève, P., Matheron, J., and Sahuc, J.G., 2010. Inflation target shocks and monetary policy inertia in the Euro area. Economic Journal 120(547), $1100-1124$.

Galí, J., 2008. Monetary Policy, Inflation and the business cycle: An introduction to the new Keynesian framework. Princeton University Press.

Gerlach-Kristen, P., 2003. Interest rate reaction functions and the Taylor rule in the Euro area. European Central Bank Working Paper No. 258.

Geweke, J.F., Keane, M.P., and Runkle, D.E., 1997. Statistical inference in the multinomial multiperiod probit model. Journal of Econometrics 80(1), 125-165.

Ireland, P.N., 2004. Money's role in the monetary business cycle. Journal of Money, Credit and Banking 36(6), 969-983.

Jacquier, E., Polson, N.G., and Rossi, P.E., 2002. Bayesian Analysis of Stochastic Volatility Models. Journal of Business and Economic Statistics 20(1), 69-87.

Mishkin, F.S., 2010. Over the cliff: From the Subprime to the Global Financial Crisis. Journal of Economic Perspectives 25(1), 49-70.

Nelson, E., 2002. Direct effects of base money on aggregate demand: theory and evidence. Journal of Monetary Economics 49(4), 687-708.

Rabanal, P., and Rubio-Ramirez, J.F., 2005. Comparing new Keynesian models of the business cycle: A Bayesian approach. Journal of Monetary Economics 52(6), 1151-1166.

Sims, C.A., and Zha, T., 1998. Bayesian Methods for Dynamic Multivariate Models. International Economic Review 39(4), 949-68.

Smets, F.R., and Wouters, R., 2003. An Estimated Dynamic Stochastic General Equilibrium Model of the Euro Area. Journal of the European Economic Association 1(5), 1123-1175. 
Smets, F., and Wouters, R., 2007. Shocks and frictions in US business cycles: a Bayesian DSGE approach. American Economic Review 97(3), 586606.

Söderström, U., 2005. Targeting inflation with a role for money. Economica $72(288), 577-596$.

Walsh, C.E., 2010. Monetary theory and policy. The MIT Press.

Woodford, M., 2003. Foundations of a Theory of Monetary Policy. Princeton University Press. 
ESSEC Business School Avenue Bernard Hirsch BP 50105

95021 Cergy-Pontoise Cedex France

Tél. +33(0)134433000

$\mathrm{Fax}+33(0) 134433001$

www.essec.fr

\section{ESSEC Executive Education}

CNIT BP 230

92053 Paris-La Défense

France

Tél. +33(0)146924900

Fax +33(0)1 46924990

http:l/formation.essec.fr

ESSEC Business School

Singapore Campus

100 Victoria Street

National Library Building \# 13-02

Singapore 188064

essecasia@essec.fr

Tél. +6568849780

Fax +6568849781

www.essec.edu

\section{Informations}

Alison Bougi

+33 (0)134433358

bougi@essec.edu

unw.essec.fr

research.center@essec.fr

ISSN 1291-9616 